\title{
Neoproterozoic metamorphic evolution of the Isbjørnhamna Group rocks from south-western Svalbard
}

\author{
Jaroslaw Majka, ${ }^{1}$ Jerzy Czerny, ${ }^{2}$ Stanislaw Mazur, ${ }^{3}$ Daniel K. Holm ${ }^{4}$ \& Maciej Manecki ${ }^{2}$ \\ 1 Department of Earth Sciences, Uppsala University, Villavägen 16, SE-75236 Uppsala, Sweden \\ 2 Department of Mineralogy, Petrography and Geochemistry, AGH-University of Science and Technology, 30 Mickiewicza Av., PL-30059 Kraków, Poland \\ 3 GETECH, Kitson House, Elmete Hall, Elmete Lane, Leeds, LS8 2LJ, UK \\ 4 Department of Geology, Kent State University, Kent, OH 44242, USA
}

\section{Keywords}

Caledonides; geothermobarometry;

metapelites; Neoproterozoic; Spitsbergen.

\section{Correspondence \\ Jaroslaw Majka, Department of Earth \\ Sciences, Uppsala University, Villavägen 16, SE-75236 Uppsala, Sweden. E-mail: \\ jaroslaw.majka@geo.uu.se}

doi:10.1111/j.1751-8369.2010.00186.x

\begin{abstract}
A metamorphosed volcano-sedimentary complex constitutes the Caledonian basement in the south-western part of Wedel Jarlsberg Land, Svalbard. Field, textural and previous thermochronologic data indicate a weak, localized metamorphic Caledonian overprint (M2). Deformed M1 isograds and variation in pressure-temperature estimates indicate a pervasive Neoproterozoic amphibolite-facies metamorphism that pre-dates large-scale Caledonian age folding. Garnet-biotite and garnet-Al silicate-plagioclase (GASP) geothermobarometry of the Isbjørnhamna Group mica schists, and their comparison with the $\mathrm{K}_{2} \mathrm{O}-\mathrm{FeO}-\mathrm{MgO}-\mathrm{Al}_{2} \mathrm{O}_{3}-\mathrm{SiO}_{2}-\mathrm{H}_{2} \mathrm{O}$ (KFMASH) petrogenetic grid, indicates a peak pressure of ca. $11 \mathrm{kbar}$, and a peak temperature of ca. $670^{\circ} \mathrm{C}$ during $\mathrm{Ml}$ metamorphism. A cooling rate of ca. $5^{\circ} \mathrm{C} \mathrm{My}^{-1}$ is estimated on the basis of geothermobarometry and the available U-Th-total $\mathrm{Pb}$ and $\mathrm{Ar}-\mathrm{Ar}$ data.
\end{abstract}

Southern Wedel Jarlsberg Land (Fig. 1) uniquely preserves a record of Neoproterozoic metamorphism on Spitsbergen, Svalbard. In situ uranium-thorium-lead electron microprobe (U-Th-Pb EMP) ages of metamorphic monazites from a Proterozoic volcano-sedimentary complex date amphibolite-grade metamorphism at ca. 643 Mya (Majka et al. 2008). The northern extent of this Neoproterozoic metamorphism is bounded by the Vimsodden-Kosibapasset zone (VKZ), which is a major strike-slip shear zone with sinistral kinematics (Fig. 2; Mazur et al. 2009). The VKZ separates the Neoproterozoic metamorphic complex from the remaining part of the south-western terranes of Svalbard, which were subjected to younger, early Palaeozoic metamorphism (Gee \& Tebenkov 2004; Czerny et al. 2010). The occurrence of a Neoproterozoic metamorphic domain in south-western Spitsbergen has important bearing on terrane concepts for Svalbard construction in general, and specifically for its proposed correlation with the Timanide metamorphic belt of north-eastern Europe (Mazur et al. 2009). A better understanding of the nature and extent of Neoproterozoic metamorphism and associated pervasive deformation, compared with earlier reports (Smulikowski 1965; Czerny et al. 1993; Majka et al. 2004), is an essential prerequisite for testing between, and refining, the tectonic models proposed for this region. In this study we: (1) quantify the peak pressure and temperature conditions for Neoproterozoic metamorphism; (2) verify the correlation between the peak of metamorphism and the pervasive deformational fabric; (3) define zones of progressive metamorphism and the relationship between isograds and major tectonic structures; and (4) constrain the cooling history of this Neoproterozoic complex. Our study is based on extensive fieldwork supported by results of microstructural analysis and geothermobarometric calculations.

\section{Geological setting}

The south-western part of Spitsbergen island exposes an elongate north-south trending metamorphic basement exhumed within the axial zone of an Early Palaeogene fold-and-thrust belt (e.g., Lowell 1972; Dallmann et al. 1993; Braathen et al. 1995; Bergh et al. 1997). This elevated basement high consists of Precambrian to Early Palaeozoic rocks, the deformation and metamorphism of which were originally ascribed solely to the Caledonian orogeny (e.g., Holtedahl 1926; Ohta 1982; Harland 1985; Harland et al. 1992). However, the occurrence of regionally extensive unconformities that are 
Fig. 1 Geological sketch map of the Svalbard Archipelago (modified from Gee \& Tebenkov 2004).

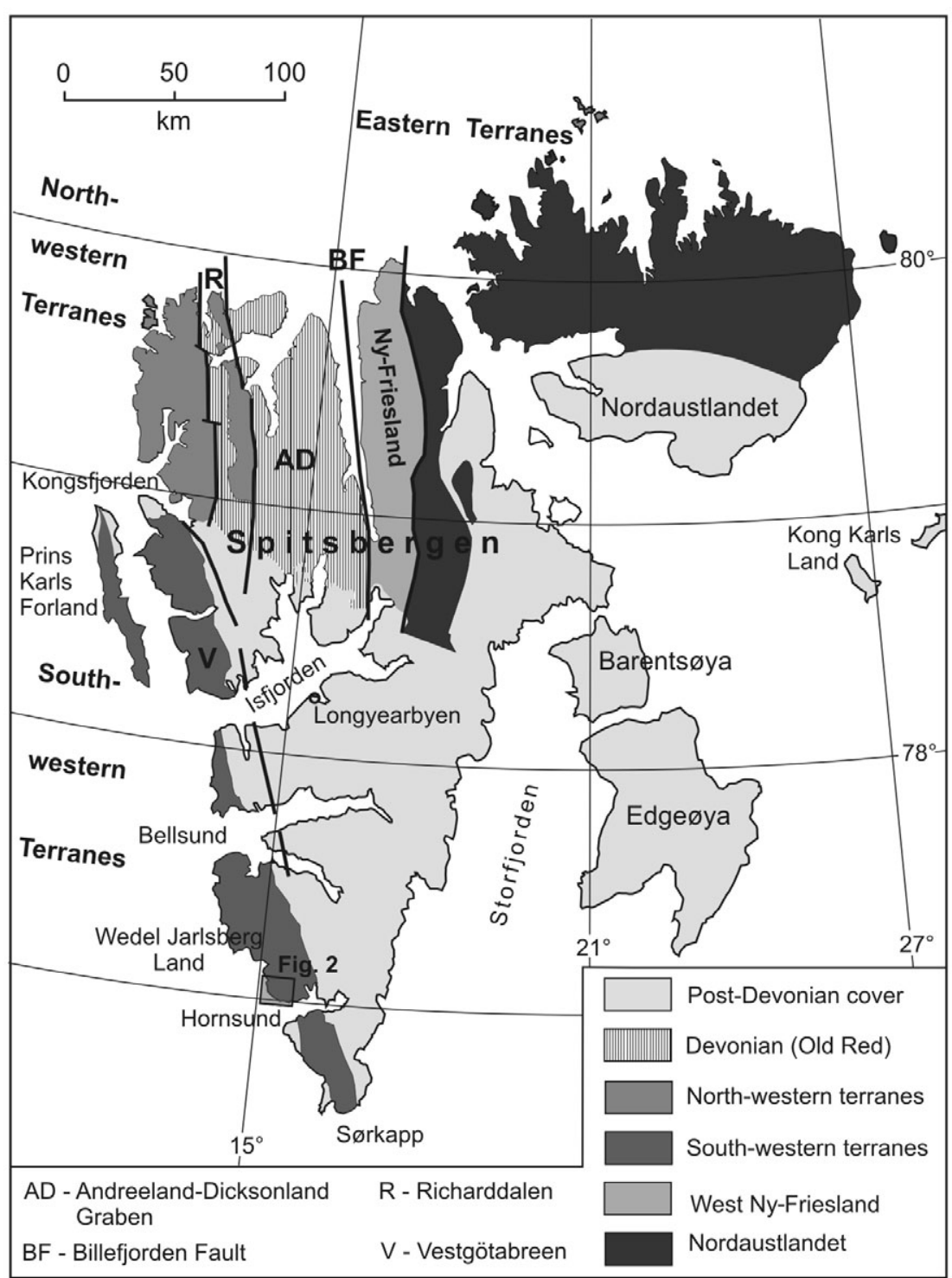

associated with metamorphic and lithological contrasts (e.g., Sandford 1956; Krasil'ščikov 1979; Birkenmajer 1975; Bjørnerud 1990) and geochronological studies both provide evidence that the Caledonian basement includes Proterozoic crustal domains juxtaposed by Early Palaeozoic tectonic events (e.g., Peucat et al. 1989; Balashov et al. 1995; Gee et al. 1995; Hellman et al. 1997; Johansson et al. 2004; Pettersson et al. 2009). These domains, together with their sedimentary cover, are interpreted to be individual tectonostratigraphic terranes assembled during the Caledonian orogeny (e.g., Harland 1972; Harland \& Gayer 1972; Gee \& Page 1994). Based on important contrasts in stratigraphy, structural development and tectonothermal evolution, the Caledonian rocks of Svalbard have been divided into eastern, north- western and south-western terranes (Fig. 1; Gee 1986; Gee \& Page 1994; Gee \& Tebenkov 2004).

North of Isfjorden, the south-western terranes of Svalbard include a blueschist-eclogite allochthon known as the Vestgötabreen complex (e.g. Ohta 1979) that yielded argon-40 ( $\left({ }^{40} \mathrm{Ar}\right)$-argon-39 $\left({ }^{39} \mathrm{Ar}\right)$ mineral cooling ages of ca. 460 My (Dallmeyer et al. 1990). The complex is non-conformably overlain by Middle Ordovician conglomerates and limestones (Armstrong et al. 1986), succeeded by Late Ordovician to Early Silurian turbidites (Scrutton et al. 1976). The metamorphic basement, together with its Early Palaeozoic cover, is thrust over a succession of diamictites of inferred Vendian age (Gee $\delta$ Tebenkov 2004). To the south of Isfjorden, the southwestern terranes consist of a Meso- to Neoproterozoic 


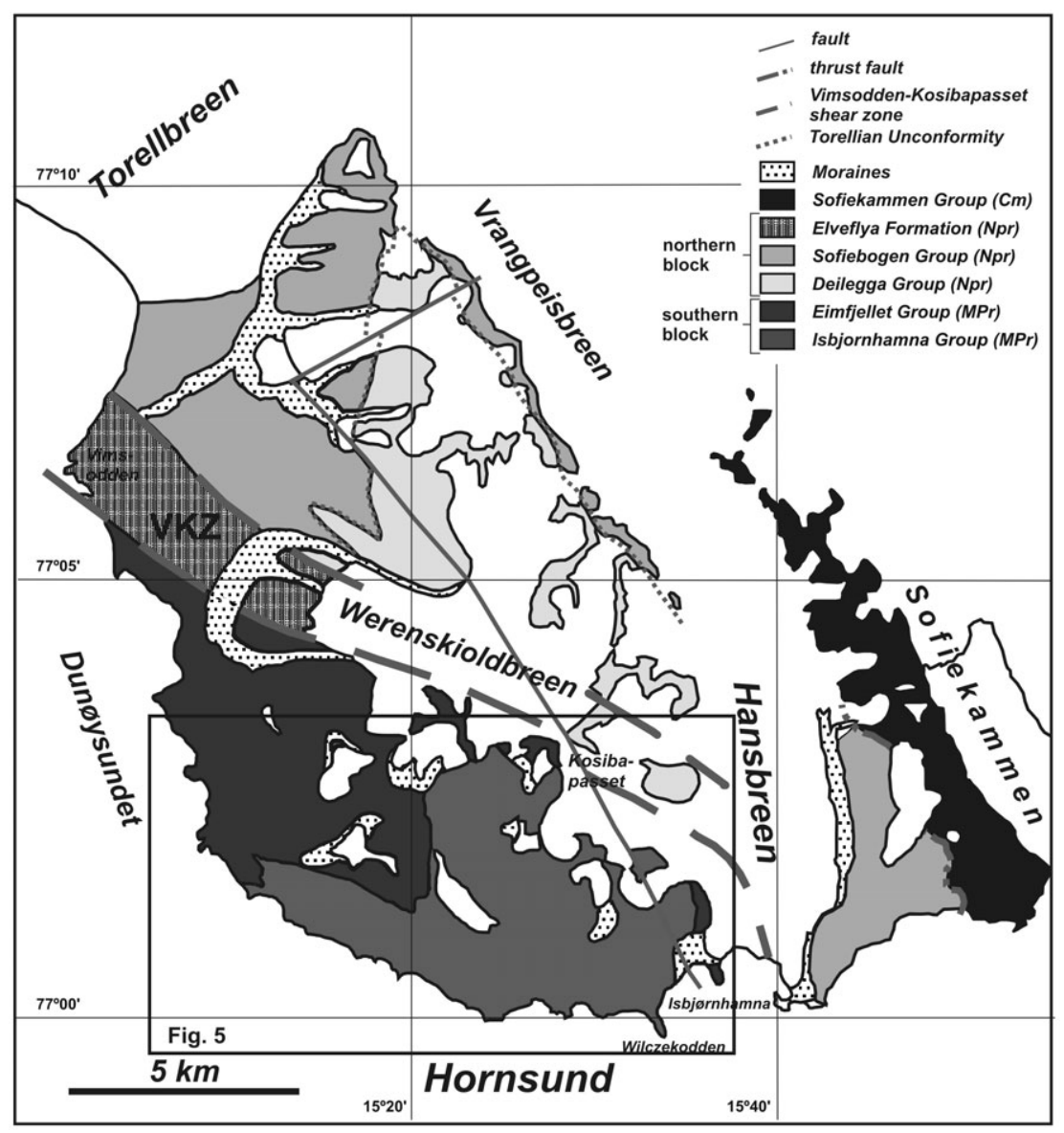

Fig. 2 Geological sketch map of the southwestern part of Wedel Jarlsberg Land (modified from Czerny et al. 1993). metamorphic complex, which is divided into three units: Isbjørnhamna, Eimfjellet and Deilegga groups (Birkenmajer 1981, 1991). The latter is non-conformably overlain by the low-grade Neoproterozoic Sofiebogen Group, comprising a succession of conglomerates, limestones and dolomites passing up into fine-grained siliciclastic rocks (Bjørnerud 1990; Czerny et al. 1993; Gee \& Tebenkov 2004). The Sofiebogen Group is capped by Vendian tillites of the Kapp Lyell Group, and comprises a thick series of diamictites (Bjørnerud 1990; Dallmann et al. 1990; Harland et al. 1993). The Cambro-Ordovician succession is tectonically emplaced atop the Proterozoic complexes (Dallmann et al. 1993; Mazur et al. 2009).

Wedel Jarlsberg Land, located in the southern part of the south-western terranes (Fig. 2), consists of two Proterozoic basement blocks with contrasting metamorphic histories. The northern block comprises rocks of the metasedimentary Deilegga and Sofiebogen groups, which are separated by a Late Proterozoic angular unconformity (Torellian unconformity; Birkenmajer 1975). The southern block corresponds to a stratified volcano-sedimentary polymetamorphic complex that consists of a metasedimentary sequence known as the Isbjørnhamna Group and a metavolcanic succession of the Eimfjellet Group (Birkenmajer 1958; Czerny et al. 1993). The Isbjørnhamna Group is composed of garnet-mica schists, paragneisses, calc-silicate rocks and marbles subjected to amphibolite-grade Barrovian metamorphism, which was followed by greenschist facies metamorphism (Smulikowski 1965; Majka et al. 2004). The Eimfjellet Group consists of quartzites, amphibolites and greenschists, accompanied by minor metarhyolites and muscovite schists. These rocks were subjected to greenschist to lower amphibolite facies (Czerny et al. 1993). The contact between the two crustal blocks exposed in the south-western part of Wedel Jarlsberg Land between the Hornsund fjord and Torellbreen glacier is represented by the ca. $2 \mathrm{~km}$ wide VKZ. The deformation zone is characterized by a heterogeneous array of structures formed during ductile shear deformation. Structural features of the VKZ indicate bulk sinistral strike-slip to oblique-slip shear strain formed under greenschist facies conditions.

Thermochronologic data obtained from the Isbjørnhamna and Eimfjellet groups indicate a Neoproterozoic age of metamorphism. ${ }^{40} \mathrm{Ar}-{ }^{39} \mathrm{Ar}$ step heating of mineral separates yielded a $616 \mathrm{My}$ age for hornblende from the 
Eimfjellet Group, and 585-575 My ages for muscovite from the Isbjørnhamna Group (Manecki et al. 1998). Manecki et al. (1998) interpreted these ages as representing a previously unrecognized episode of Neoproterozoic reheating, probably connected with the opening of the Iapetus Ocean. Corroborating evidence of a Neoproterozoic tectonothermal event is provided by a metamorphic monazite age of $643 \pm 9$ My recently obtained from the Isbjørnhamna Group (Majka et al. 2008). This age was interpreted to represent the progressive phase of a regional metamorphic event, as monazite grains enclosed in garnet porphyroblasts yielded the same age as matrix monazite grains. A somewhat younger Neoproterozoic age (615 My) was obtained on zircons separated from an anatectic pegmatite, which intrudes the Isbjørnhamna Group (Majka et al. 2007).

\section{Description of metamorphic units}

The Isbjørnhamna Group consists of the Skoddefjellet, Ariekammen and Revdalen formations, representing an originally continuous sedimentary succession (Birkenmajer 1975).

\section{Skoddefjellet Formation}

The Skoddefjellet Formation is composed of interlayered paragneisses and mica schists. Typical prograde mineral assemblages in these rocks are $\mathrm{Qtz}+\mathrm{Pl}+\mathrm{Bt}+\mathrm{Ms} \pm$ Grt \pm Chl with greater quantities of plagioclase in paragneisses and garnet in mica schists.

The mica schists are well foliated with common garnet and biotite porphyroblasts. The matrix is mainly composed of quartz, plagioclase $(<15 \%$ vol. $)$ and phyllosilicates. Biotite occurs mainly within the foliation planes, in the pressure shadows of garnet and as a product of garnet decomposition. Additionally, biotite forms porphyroblasts transverse to the foliation and enriched in small graphite inclusions. Very rarely biotite occurs as inclusions in garnet. Muscovite occurs mainly in foliation planes, in the pressure shadows of garnet and sometimes replacing garnet porphyroblasts. Primary chlorite occurs in the foliation planes, whereas secondary chlorite replaces micas in the pressure shadows of garnet and occurs as rosettes within the matrix. The accessory phases comprise tourmaline, apatite, zircon, monazite, epidote group minerals, titanite, ilmenite, hematite, pyrite, pyrotite and chalcopyrite.

\section{Ariekammen Formation}

The Ariekammen Formation is characterized by the occurrence of carbonate rocks. The formation mostly consists of carbonate-mica schists, with irregular bands of mica schists, paragneisses of the Skoddefjellet type and minor marble intercalations. A mineral assemblage characteristic of carbonate-mica schists comprises Cal + $\mathrm{Qtz}+\mathrm{Bt}+\mathrm{Grt}+\mathrm{Pl}+\mathrm{Ms} \pm \mathrm{Ep}$, with Ca-enriched plagioclase and accessory minerals similar to those found in the Skoddefjellet Formation. Additionally, some schist varieties contain rare mejonite. Notably, a thin discontinuous horizon of yellow and white marble occurs in the middle of the formation. Porphyroblasts of garnet up to $6 \mathrm{~cm}$ in diameter are abundant at the base of this horizon.

\section{Revdalen Formation}

The Revdalen Formation represents a uniform sequence of rusty weathered mica schist composed of Qtz $+\mathrm{Pl}$ $+\mathrm{Ms} \pm \mathrm{Bt} \pm \mathrm{Grt} \pm \mathrm{St} \pm \mathrm{Ky} \pm \mathrm{Cld} \pm \mathrm{Chl}$. Metamorphic isograds within these rocks are defined by the local presence of chloritoid, staurolite or kyanite. The mica schists are well foliated with numerous garnet porphyroblasts and rare transversal biotite and staurolite porphyroblasts. The matrix mostly consists of quartz and phyllosilicates and minor plagioclase. Muscovite occurs in all varieties of the Revdalen mica schists, whereas biotite is absent from chloritoid-bearing samples, which tend to be rich in primary chlorite. All phyllosilicate types can be found in the pressure shadows of garnet and staurolite, and both micas exist as inclusions in garnet. Rare kyanite occurs in samples containing garnet and/or staurolite. The remaining accessory phases comprise abundant tourmaline, zircon, monazite, apatite, epidote (sometimes allanite), titanite, rutile, and Fe-oxides and -sulphides. Additionally, some younger Fe-oxyhydroxides and carbonates are also present.

\section{Description of textures}

The Isbjørnhamna metapelites exhibit a penetrative planar S1 foliation, a well-developed L1 mineral stretching lineation, particularly in the skoddefjellet mica schists, and locally developed S-C fabrics (most common in the Revdalen Formation). The $\mathrm{S} I$ foliation is expressed by aligned phyllosilicates and flattened garnet and staurolite porphyroblasts (Fig. 3). Deformation resulted in the ductile flattening of garnets and the development of asymmetric pressure shadows filled with biotite, muscovite, quartz and plagioclase. The flattened and slightly rotated garnets often contain helicitic inclusions. Inclusion trails in rare euhedral garnet porphyroblasts, occurring in low strain zones, parallel the S1 foliation. Some staurolite porphyroblasts are slightly flattened and accompanied by pressure shadows filled with muscovite and quartz. In many cases, however, staurolite grains are 

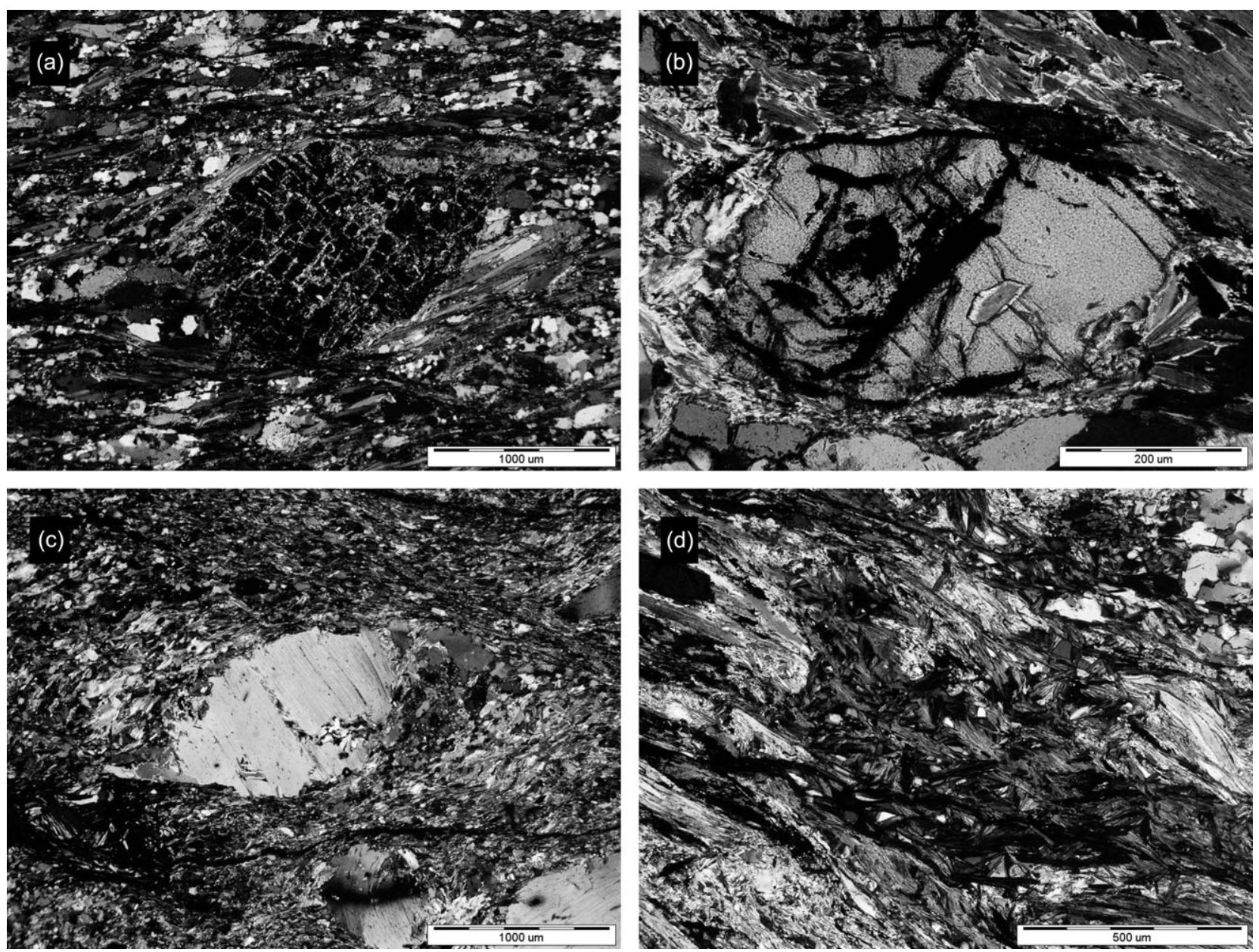

Fig. 3 Photomicrographs of (a) slightly rotated anhedral garnet with asymmetrically developed pressures shadows and its relationship to biotite; (b) deformed and slightly rotated staurolite; (c) deformed large biotite; and (d) retrogressive rosette-shaped chlorite.

inclusion-free and euhedral, with only narrow asymmetric mica-filled pressure shadows.

The transversal character of biotite porphyroblasts is expressed by the orientation of their cleavage planes that are oblique to the $\mathrm{S} 1$ foliation. The cleavage is underlined by common graphitic encrustations, possibly representing a relict So layering. The biotite porphyroblasts are flattened and accompanied by asymmetric tails of finegrained biotite.

\section{$M_{1}$ metamorphism}

Metamorphic isograds are well-defined within the metapelites of the Revdalen Formation. For samples collected in the north-western part of the study area, from the western limb of a north-south trending anticline outcropping in the Rålstranda, the prograde Ml mineral assemblage is defined by $\mathrm{Grt}+\mathrm{Cld}+\mathrm{Ms}+\mathrm{Chl}+\mathrm{Qtz} \pm \mathrm{Pl}$. Chloritoid-bearing and biotite-absent metapelites occur exclusively in the region of the Russepynten cape. Eastwards from that region, the mineral assemblage changes into $\mathrm{Grt}+\mathrm{Bt}+\mathrm{Ms}+\mathrm{Qtz} \pm \mathrm{Pl} \pm \mathrm{Chl}$ and farther east into $\mathrm{Grt}+\mathrm{St}+\mathrm{Ms}+\mathrm{Bt}+\mathrm{Qtz} \pm \mathrm{Pl} \pm \mathrm{Chl}$. By contrast, in the east and south-eastern part of the study area (Revdalen, Skålfjelldalen and Fugleberget), the mineral paragenesis is defined by the occurrence of $\mathrm{Grt}+\mathrm{Ms}+\mathrm{Bt}+\mathrm{Qtz} \pm$ $\mathrm{Pl}$, whereas only in a very few cases are additional kyanite or kyanite and staurolite recorded. The rare occurrence of Al-saturated phases is related to local changes in bulk rock composition. In the schists from the Rålstranda area, very fine-grained progressive allanite and epidote were observed, whereas farther east and south the dominant rare earth element-bearing phase is monazite. The transition of allanite into monazite is consistent with the increasing metamorphic grade within the Revdalen Formation to the east because allanite is stable only at upper greenschist to lower amphibolite facies conditions; with increasing temperatures, allanite is 
replaced by monazite (e.g., Ferry 2000; Janots et al. 2007).

\section{Retrogressive stage of $M_{1}$ metamorphism}

A retrogressive alteration was associated with cooling after the peak of Ml metamorphism. In many cases, retrogression resulted in the partial or complete replacement of garnet by the assemblage of $\mathrm{Bt}+\mathrm{Ms}+\mathrm{Pl}+\mathrm{Q} \pm$ Chl or $\mathrm{Pl}+\mathrm{Q} \pm \mathrm{Chl}$. Partial replacement of biotite by chlorite may also be related to this phase of metamorphic evolution. Additionally, the partial or even complete replacement of monazite by apatite-allanite-epidote coronas in some samples is a common reaction indicative of late-metamorphic cooling (e.g., Ferry 2000; Majka \& Budzyń 2006, Janots et al. 2007, Broska \& Majka 2008). The character of the retrogressive changes and the mineral assemblage synchronously formed suggest that retrogression took place shortly after the peak of $\mathrm{Ml}$ metamorphism.

\section{Weak Caledonian $\mathbf{M}_{2}$ overprint}

The Isbjørnhamna Group belongs to Proterozoic basement exposed in the core of the West Spitsbergen foldand-thrust belt. The main Caledonian structure in the study area is the VKZ trending from north-west to southeast (Czerny et al. 1993; Mazur et al. 2009). The effects of Caledonian deformation are widespread to the north of this zone. Contrastingly, southwards from the VKZ, Caledonian overprint rapidly dies out in the rigid amphibolite facies tectonic block, including the Isbjørnhamna Group. Only the rocks of the Eimfjellet Group, which are adjacent to the VKZ, experienced intense Caledonian mylonitization (Mazur et al. 2009), whereas the rocks of the Isbjørnhamna Group do not reveal any significant Caledonian reworking, except in a few relatively thin zones of altered rocks, usually parallel with VKZ. The only visible effect of the Caledonian event is the partial or sometimes complete chloritization of garnet, biotite and staurolite, as well as the alteration of muscovite porphyroblasts to sericite. Additionally, in some cases Caledonian alterations are expressed by the development of sericite reaction rims on kyanite, and by sericitization of staurolite and plagioclase. These changes probably took place under static conditions, as indicated by the common growth of rosette-like chlorite neoblasts (Fig. 3).

\section{Mineral chemistry}

Selected minerals were chemically analysed using wavelength dispersive spectrometry with the lo0SX electron microprobe (Cameca, Grennevilliers Cedex, France) at the Inter-Institute Analytical Complex for Minerals and Synthetic Substances, University of Warsaw. The operating conditions were set at $15 \mathrm{kV}, 20 \mathrm{nA}$ and $20 \mathrm{~s}$ of the counting time using natural and synthetic standards. The data were calculated using atomic number, absorption and fluorescence (ZAF) corrections.

\section{Garnets}

Garnets were analysed along rim-core-rim profiles. Porphyroblasts of garnet were selected from different metamorphic zones within the Revdalen and the Skoddefjellet formations. Representative traverses are shown in Fig. 4. A common feature of garnets from the kyanitefree mica schists (i.e., samples 206, 214 and 125) is the systematic increase of pyrope content from the core to rims, and the contemporary decrease of $\mathrm{Fe} /(\mathrm{Fe}+\mathrm{Mg})$ and spessartine content. The rimward decrease of $\mathrm{Fe} /(\mathrm{Fe}+\mathrm{Mg})$ is characteristic of the increase of temperature under upper greenschist and amphibolite facies conditions (Spear 1993). The bell-shaped spessartine profile also suggests prograde growth zoning during a one-stage chemical reaction (Tracy 1982). The slight increase of spessartine content that was observed in some garnet rims may be related to the consumption of garnet. Notably, garnet from the staurolite-bearing mica schists reveals a decrease of $\mathrm{Fe} /(\mathrm{Fe}+\mathrm{Mg})$ towards the rims, but in the rims this tendency changes and $\mathrm{Fe} /(\mathrm{Fe}+\mathrm{Mg})$ is flat or even slightly increased. The almandine content in this garnet systematically increases towards the rims, but in the rims it decreases. The opposite trend is evident for the grossular content, which systematically decreases towards the rims, but rapidly increases in the rims. The variation of grossular and almandine content in garnets co-existing with staurolite may have been caused by the onset of staurolite crystallization (see also Janák et al. 2001): the onset of staurolite crystallization could modify local chemical equilibrium during garnet crystallization, decreasing the almandine content in garnet, as observed in our samples. Contemporaneously, the observed enrichment in $\mathrm{Ca}$ is probably caused by the reduction of crystallization of plagioclase in response to the appearance of a new Al-saturated phase (e.g., staurolite). Nevertheless, the smooth shape of decreasing spessartine content suggests prograde growth during a single metamorphic event.

The compositional variation in garnet from the kyanite-bearing mica schist (i.e., sample 124) is complex. In all cases the profiles are strongly disturbed, probably as a result of the presence of numerous tiny inclusions and the diffusion that occurred between them and the hosting garnet. Nevertheless, the almandine and pyrope zoning 

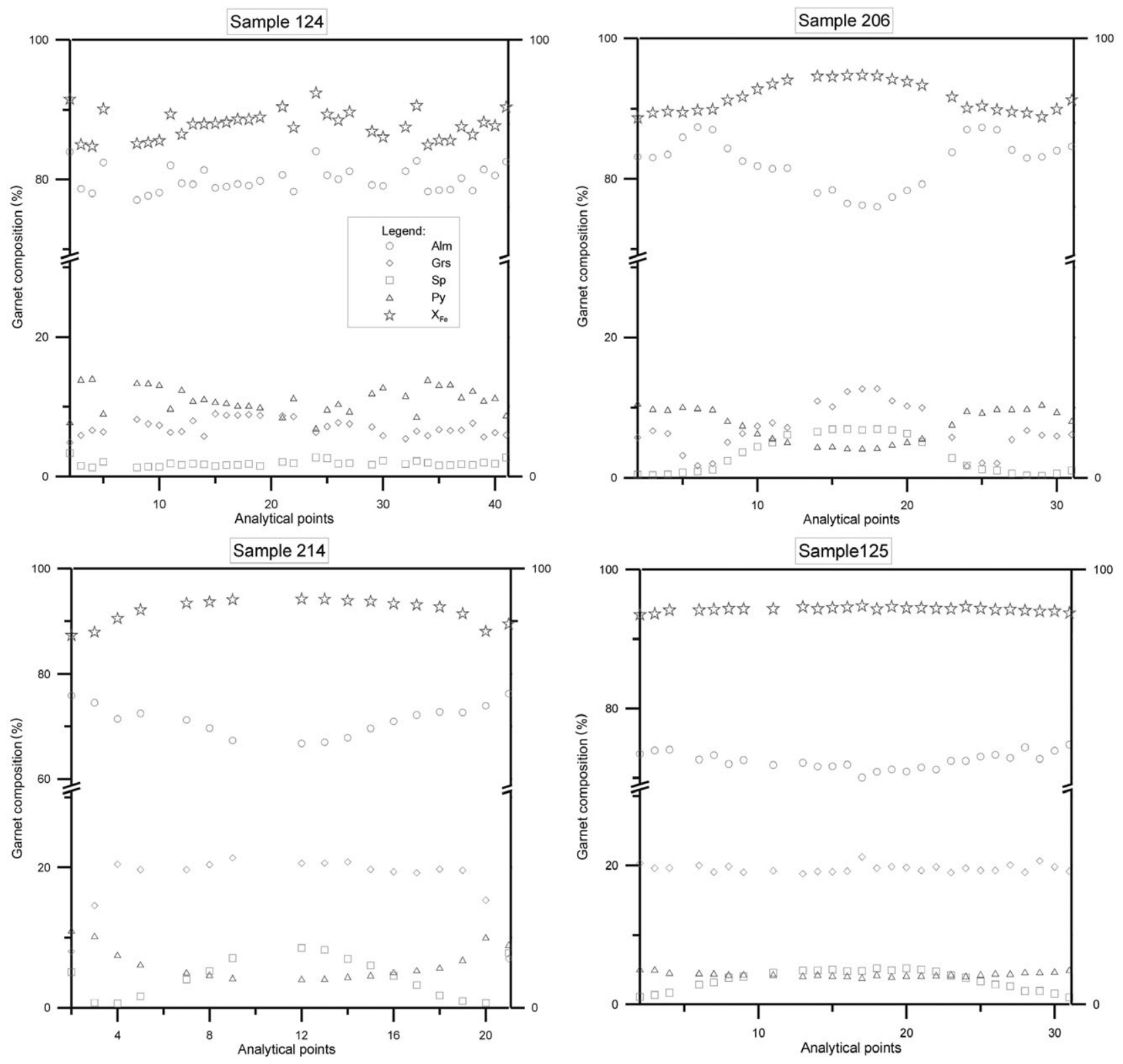

Fig. 4 Examples of typical profiles through garnets from samples 124 (high-Al mica schist of Revdalen Formation, zone 4, diameter =1.7 mm), 125 (low-Al mica schist of the Revdalen Formation; diameter $=1.5 \mathrm{~mm}$ ), 206 (high-Al mica schist of the Revdalen Formation, zone 2, diameter =1.3 mm), 214 (low Al mica schist of the Skoddefjellet Formation, diameter $=1 \mathrm{~mm}$ ), showing the differences in garnet zoning between high-Al Revdalen Formation, low-Al Revdalen Formation and low-Al Skoddefjellet Formation mica schists, as well as within zones 2 and 4 in the Revdalen Formation.

suggest garnet growth during prograde metamorphism, although the distribution of spessartine and grossular content seem to be homogenized. If so, this homogenization may have occurred during an early stage of retrogression (Spear 1993), connected with a general decrease of pressure.

Garnets from the high-Al Revdalen Formation schists (i.e., samples 124 and 206) are characterized by relatively lower grossular and higher almandine content, compared with low-Al Revdalen Formation and Skoddefjellet Formation schists (samples 125 and 214, respectively).

\section{Staurolite}

Staurolite porphyroblasts as well as staurolite enclosed in garnets do not reveal any chemical zonation. They are Fe-staurolites, with Fe in the range of 1.55-1.74 atoms per formula unit (apfu) and $\mathrm{Mg}$ in the range of 


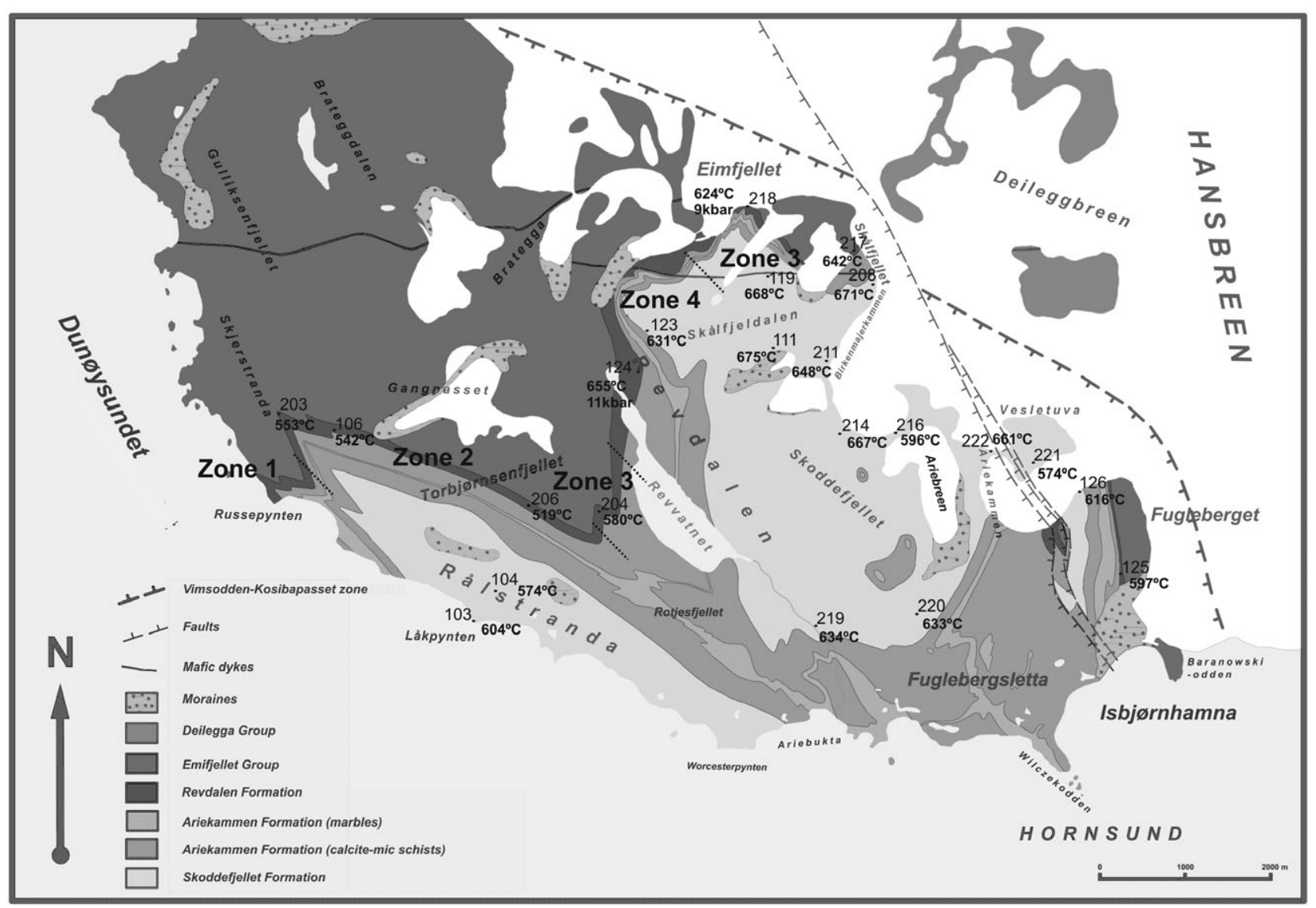

Fig. 5 Sample locations with the temperatures obtained and boundaries of mineral zones within the Isbjørnhamna Group.

$0.21-0.29 \mathrm{apfu}$. The $\mathrm{Fe} /(\mathrm{Fe}+\mathrm{Mg})$ ratio is in the range $0.85-0.88$ (Table 1).

\section{Biotite}

Biotite contains ${ }^{\mathrm{VI}} \mathrm{Al}$ in the range of 0.653-0.86 apfu and $\mathrm{Fe} /(\mathrm{Fe}+\mathrm{Mg})$ in the range of $0.57-0.697$ (Table 2). Ti content in the biotites scatters in the range of $0.085-$ $0.295 \mathrm{apfu}$, which is characteristic for biotites from mesozonal rocks of Barrovian facies series (Henry et al. 2005). Only biotites occurring in foliation planes in the vicinity of garnets were used for further geothermobarometric calculations, except sample 124, where we used matrix biotite not in contact with garnet.

\section{Plagioclase}

Plagioclase crystals differ from each other, depending on their position in the fabric of the mica schists. Plagioclase grains in contact with garnet or partially replacing it have an anorthite content in the range of $0.1-0.17$. Plagioclase grains from the matrix are characterized by a relatively lower level of anorthite molecules of 0.09-0.12 (Table 1). These porphyroblasts probably crystallized near the maximum pressure conditions during the Dl deformation. Plagioclase grains characterized by the higher level of anorthite molecules presumably formed early during the first stage of decompression, after the pressure associated with the peak of metamorphism, but still under increasing temperature. The lower An plagioclases, located in the matrix, were used for further geobarometrical calculations.

\section{Pressure-temperature estimates}

\section{Metamorphic zones}

The petrography and mineral chemistry of the Isbjørnhamna Group described above point to regional amphibolite facies metamorphism. The observed mineral parageneses in the metapelites are grouped into four metamorphic zones: zone 1 , with $\mathrm{Cld}+\mathrm{Chl}+\mathrm{Grt}$ paragenesis in high-Al mica schists, and $\mathrm{Chl}+\mathrm{Bt}+\mathrm{Grt}$ paragenesis in low-Al mica schists; zone 2, with 
Table 1 Chemical composition of plagioclases used for garnet-Al silicate-plagioclase (GASP) geobarometry (with obtained pressures) and chemical composition of staurolites from the Isbjørnhamna Group metapelites.

\begin{tabular}{|c|c|c|c|c|c|c|c|c|c|c|}
\hline \multirow[b]{2}{*}{$\mathrm{Pl}$} & \multicolumn{5}{|l|}{ Sample } & \multirow[b]{2}{*}{ St } & \multicolumn{4}{|l|}{ Sample } \\
\hline & $124-1$ & $124-2$ & $124-3$ & $218-1$ & $218 \mathrm{~A}-2$ & & 204-core & 204-rim & 206-core & 206-rim \\
\hline $\mathrm{SiO}_{2}$ & 64.853 & 66.114 & 65.742 & 64.918 & 65.944 & $\mathrm{SiO}_{2}$ & 27.815 & 27.827 & 27.544 & 27.473 \\
\hline $\mathrm{Al}_{2} \mathrm{O}_{3}$ & 22.478 & 21.669 & 21.677 & 21.950 & 21.393 & $\mathrm{TiO}_{2}$ & 0.428 & 0.596 & 0.509 & 0.638 \\
\hline $\mathrm{CaO}$ & 3.114 & 2.095 & 2.306 & 3.325 & 2.513 & $\mathrm{Al}_{2} \mathrm{O}_{3}$ & 53.190 & 54.364 & 53.379 & 53.274 \\
\hline $\mathrm{FeO}$ & 0.098 & 0.074 & 0.059 & 0.456 & 0.031 & MgO & 1.391 & 1.208 & 1.112 & 0.988 \\
\hline BaO & 0.000 & 0.000 & 0.072 & na & na & $\mathrm{CaO}$ & 0.006 & 0.024 & 0.000 & 0.000 \\
\hline $\mathrm{Na}_{2} \mathrm{O}$ & 10.167 & 10.422 & 10.181 & 9.735 & 10.198 & MnO & 0.070 & 0.038 & 0.037 & 0.030 \\
\hline $\mathrm{K}_{2} \mathrm{O}$ & 0.022 & 0.000 & 0.031 & 0.039 & 0.007 & $\mathrm{FeO}$ & 14.839 & 13.934 & 13.478 & 13.227 \\
\hline \multirow[t]{2}{*}{ Total } & 100.733 & 100.374 & 100.068 & 100.423 & 100.086 & Zno & 0.034 & 0.033 & 0.202 & 0.286 \\
\hline & & & & & & $\mathrm{H}_{2} \mathrm{O}$ & 2.149 & 2.167 & 2.129 & 2.123 \\
\hline $\mathrm{Si}$ & 2.839 & 2.891 & 2.886 & 2.853 & 2.894 & Total & 99.922 & 100.191 & 98.390 & 98.039 \\
\hline Al & 1.160 & 1.117 & 1.122 & 1.137 & 1.106 & & & & & \\
\hline $\mathrm{Ca}$ & 0.146 & 0.098 & 0.108 & 0.157 & 0.118 & $\mathrm{Si}$ & 3.880 & 3.851 & 3.879 & 3.880 \\
\hline $\mathrm{Fe}$ & 0.004 & 0.003 & 0.002 & 0.017 & 0.001 & $\mathrm{Ti}$ & 0.045 & 0.062 & 0.054 & 0.068 \\
\hline $\mathrm{Ba}$ & 0.000 & 0.000 & 0.001 & na & na & Al & 8.745 & 8.867 & 8.859 & 8.867 \\
\hline $\mathrm{Na}$ & 0.863 & 0.884 & 0.867 & 0.829 & 0.868 & Mg & 0.289 & 0.249 & 0.233 & 0.208 \\
\hline K & 0.001 & 0.000 & 0.002 & 0.002 & 0.000 & $\mathrm{Ca}$ & 0.001 & 0.004 & 0.000 & 0.000 \\
\hline \multirow[t]{2}{*}{ Total } & 5.013 & 4.992 & 4.988 & 4.995 & 4.987 & $\mathrm{Mn}$ & 0.008 & 0.005 & 0.004 & 0.004 \\
\hline & & & & & & $\mathrm{Fe}$ & 1.731 & 1.613 & 1.587 & 1.562 \\
\hline$A b$ & 85.420 & 90.000 & 88.610 & 83.907 & 88.032 & $\mathrm{Zn}$ & 0.004 & 0.003 & 0.021 & 0.030 \\
\hline An & 14.460 & 10.000 & 11.090 & 15.891 & 11.968 & Total & 14.703 & 14.654 & 14.637 & 14.619 \\
\hline Or & 0.120 & 0.000 & 0.180 & 0.202 & 0.000 & & & & & \\
\hline Cs & 0.120 & 0.000 & 0.180 & - & - & $\mathrm{Fe} /(\mathrm{Fe}+\mathrm{Mg})$ & 0.857 & 0.866 & 0.872 & 0.882 \\
\hline P(kbar) & 9.84 & 11.22 & 11.29 & 6.60 & 8.77 & & & & & \\
\hline
\end{tabular}

Derived $2 \sigma$ errors of ca. 0.8 kbar for geobarometry (Holdaway 2000,2001 ) have been used.

Table 2 Chemical composition of garnets and biotites used for geothermometry and obtained temperatures.

\begin{tabular}{|c|c|c|c|c|c|c|c|c|}
\hline \multirow[b]{2}{*}{ Sample } & \multicolumn{5}{|l|}{ Grt } & \multicolumn{3}{|l|}{$\mathrm{Bt}$} \\
\hline & Py & Alm & Grs & Sps & $\mathrm{Fe} /(\mathrm{Fe}+\mathrm{Mg})$ & $\mathrm{Fe} /(\mathrm{Fe}+\mathrm{Mg})$ & $\mathrm{Ti}$ & Temp. \\
\hline 103 & 9.685 & 77.446 & 11.045 & 1.824 & 0.889 & 0.578 & 0.235 & 604 \\
\hline 104 & 8.337 & 79.280 & 11.623 & 0.759 & 0.905 & 0.579 & 0.190 & 574 \\
\hline 106 & 4.887 & 67.799 & 19.082 & 8.233 & 0.933 & 0.613 & 0.194 & 542 \\
\hline 111 & 9.490 & 75.572 & 11.779 & 3.158 & 0.888 & 0.614 & 0.085 & 675 \\
\hline 119 & 9.312 & 74.120 & 14.692 & 1.876 & 0.888 & 0.640 & 0.182 & 668 \\
\hline 123 & 8.521 & 76.359 & 11.180 & 3.940 & 0.900 & 0.634 & 0.231 & 631 \\
\hline 124 & 8.830 & 81.673 & 6.581 & 2.916 & 0.902 & 0.594 & 0.222 & 655 \\
\hline 125 & 6.010 & 71.476 & 19.426 & 3.088 & 0.922 & 0.655 & 0.282 & 597 \\
\hline 126 & 7.536 & 70.953 & 16.620 & 4.891 & 0.904 & 0.618 & 0.143 & 616 \\
\hline 203 & 6.679 & 66.571 & 22.196 & 4.554 & 0.909 & 0.517 & 0.173 & 553 \\
\hline 204 & 8.033 & 84.134 & 5.774 & 2.059 & 0.913 & 0.583 & 0.158 & 580 \\
\hline 206 & 7.402 & 89.433 & 1.945 & 1.220 & 0.924 & 0.576 & 0.203 & 519 \\
\hline 208 & 8.672 & 67.678 & 20.397 & 3.252 & 0.886 & 0.627 & 0.169 & 671 \\
\hline 211 & 6.166 & 71.925 & 17.383 & 4.526 & 0.921 & 0.657 & 0.178 & 648 \\
\hline 214 & 10.195 & 74.263 & 13.343 & 2.199 & 0.879 & 0.623 & 0.232 & 667 \\
\hline 216 & 10.090 & 80.443 & 6.284 & 3.183 & 0.889 & 0.572 & 0.192 & 596 \\
\hline 217 & 10.376 & 82.923 & 3.292 & 3.409 & 0.889 & 0.627 & 0.209 & 642 \\
\hline 218 & 13.610 & 80.204 & 4.727 & 1.458 & 0.855 & 0.582 & 0.185 & 624 \\
\hline 219 & 8.218 & 71.436 & 20.230 & 0.116 & 0.897 & 0.572 & 0.137 & 634 \\
\hline 220 & 7.867 & 72.259 & 9.391 & 10.484 & 0.902 & 0.637 & 0.234 & 633 \\
\hline 221 & 6.559 & 76.095 & 16.880 & 0.466 & 0.921 & 0.626 & 0.148 & 574 \\
\hline 222 & 8.337 & 79.280 & 11.623 & 0.759 & 0.905 & 0.579 & 0.190 & 661 \\
\hline
\end{tabular}

Derived $2 \sigma$ errors of ca. $25^{\circ} \mathrm{C}$ for geothermometry (Holdaway 2000,2001 ) have been used. 
$\mathrm{Chl}+\mathrm{Grt}+\mathrm{St} \pm \mathrm{Bt}$ paragenesis in high-Al mica schists, and $\mathrm{Grt}+\mathrm{Chl}+\mathrm{Bt}$ paragenesis in low-Al mica schists; zone 3, with $\mathrm{Grt}+\mathrm{St}+\mathrm{Bt}+\mathrm{Ky} \pm \mathrm{Chl}$ assemblage in high-Al mica schists and $\mathrm{Grt}+\mathrm{Bt}+\mathrm{St} \pm \mathrm{Chl}$ in low-Al mica schists; zone 4, with $\mathrm{Grt}+\mathrm{Ky}+\mathrm{Bt}$ in high-Al mica schists and Grt + Bt in low-Al mica schists.

Metamorphic isograds are defined on the first occurrence of the AFM mineral. The boundary between zones 1 and 2 was delineated by the first appearance of staurolite. The mineral assemblage for zone 2 was recognized only in one sample of high-Al mica schists, and thus the boundary between zones 1 and 2 is speculative. The boundary between zones 2 and 3 is defined by the broad appearance of biotite and staurolite and between zones 3 and 4 by the disappearance of staurolite. The observed parageneses and metamorphic zones suggest a sequence of index mineral reactions characteristic of continuously increasing pressure-temperature $(\mathrm{P}-\mathrm{T})$ conditions from upper greenschist to middle/upper amphibolite facies conditions at moderate to high pressure. Metamorphic zoning without a chloritoid + biotite assemblage is well recognized in several kyanite-bearing metamorphic complexes (e.g., Spear 1993; Bucher and Frey 1994).

\section{Geothermobarometry}

We used the garnet-Al silicate-plagioclase (GASP) geobarometer (Holdaway 2001) to quantitatively estimate the peak pressure conditions. The pressure was calculated only in samples containing an $\mathrm{Al}_{2} \mathrm{SiO}_{5}$ polymorph (kyanite in this case). Only five plagioclase-garnet pairs were analysed in both samples, mainly because of strong retrogressive changes. Those analysed, however, were not affected by strong retrogression. The results obtained are in the range of 9.84-11.3 kbar for sample 124, and 6.6-8.77 kbar for sample 218 (see Table 2 and Fig. 5 for the location of samples), and are relatively consistent with pargeneses observed in the investigated samples.

For peak temperature estimation, the garnet-biotite geothermometer (Holdaway et al. 1997; Holdaway 2000) was used. The temperatures were calculated for a normative pressure of $9 \mathrm{kbar}$ on the basis of mineral paragenesis and previous preliminary pressure estimates (Majka 2003; Majka et al. 2004). The lowest Fe/(Fe + Mg) values (usually rim) were used for further geothermometrical calculations. The calculated temperatures are scattered in the range of $530-675^{\circ} \mathrm{C}$ (Fig. 5; Table 2). The general tendency observed in the Isbjørnhamna Group is that calculated temperatures increase from 519 to $604^{\circ} \mathrm{C}$ in the Rålstranada area (samples 103, 104, 106 and 203), and from 624 to $675^{\circ} \mathrm{C}$ in the upper Revdalen area (samples 119, 123, 124, 208, 217 and 218), which appears in the core of the Ariebreen anticline (samples
111,211 and 214). Slightly lower temperatures (596$634^{\circ} \mathrm{C}$ ) were recorded for the samples collected from the south and south-east limb of the Ariebreen anticline (samples 216, 219 and 220). Similarly, for the samples from the Fuglebereget-Vesletuva area (samples 125, 126, 221 and 222), temperatures in the range of $574-628^{\circ} \mathrm{C}$ were obtained.

\section{Comparison of geothermobarometrical results and KFMASH petrogenetic grid}

The $\mathrm{K}_{2} \mathrm{O}-\mathrm{FeO}-\mathrm{MgO}-\mathrm{Al}_{2} \mathrm{O}_{3}-\mathrm{SiO}_{2}-\mathrm{H}_{2} \mathrm{O}$ (KFMASH) petrogenetic grid (Spear \& Cheney 1989) was used to better constrain the P-T path based on our geothermobarometric results. Only the samples from the Revdalen Formation, showing well-developed metamorphic zonation, were used. Observed mineral prageneses of high-Al mica schists can be represented by the KFMASH system. $\mathrm{The} \mathrm{Fe} /(\mathrm{Fe}+\mathrm{Mg})$ ratios in analysed minerals decreases in the order garnet $>$ staurolite $>$ biotite, similar to many metapelites from all over the world (e.g., Thompson 1976; Spear 1993). Therefore, we decided to ignore the minor components $\mathrm{MnO}, \mathrm{Na}_{2} \mathrm{O}, \mathrm{TiO}_{2}$ and $\mathrm{CaO}$ while choosing the petrogenetic grid. The paragenetic mineral assemblage in samples with the lowest metamorphic grade in the Revdalen Formation, which crop out in the Russepynten cape area, indicates that these rocks were metamorphosed above the chloritoid and garnet isograds. The lack of biotite in this mica schist variety does not mean that these rocks were formed below the biotite isograd. In accordance with the KFMASH system, the co-existence of chloritoid, chlorite and garnet in the paragenesis means that chloritoid-bearing mica schists could have been formed in the temperature range of $450-520^{\circ} \mathrm{C}$. Only above the temperature of ca. $520^{\circ} \mathrm{C}$ is chlorite replaced by the garnet-biotite assemblage. Similarly, chloritoid can be unstable, but in very specific cases it is stable up to $550^{\circ} \mathrm{C}$ (Bucher \& Frey 1994).

More eastwards but still in the Rålstranda and Torbjørnsenfjellelt areas the index mineral assemblage changes into $\mathrm{Grt}+\mathrm{Bt}+\mathrm{Chl}, \mathrm{Grt}+\mathrm{St} \pm \mathrm{Bt} \pm \mathrm{Chl}$ and $\mathrm{Grt}+\mathrm{Bt}+\mathrm{St} \pm \mathrm{Chl}$. Such a change means an increase in temperature above $520^{\circ} \mathrm{C}$ for samples without staurolite, and a further increase in temperature above $550^{\circ} \mathrm{C}$ in rocks containing staurolite. The stability of the latter paragenesis is restricted much more by pressure than by temperature. Generally, the maximum temperature of staurolite stability decreases with an increase in pressure. The obtained temperature of $580^{\circ} \mathrm{C}$ for sample 204 probably corresponds to a pressure of 8-9 kbar.

Further east in the upper Revdalen Valley region, staurolite disappears from the paragenesis, and is replaced by kyanite. This paragenetic mineral assemblage is stable 


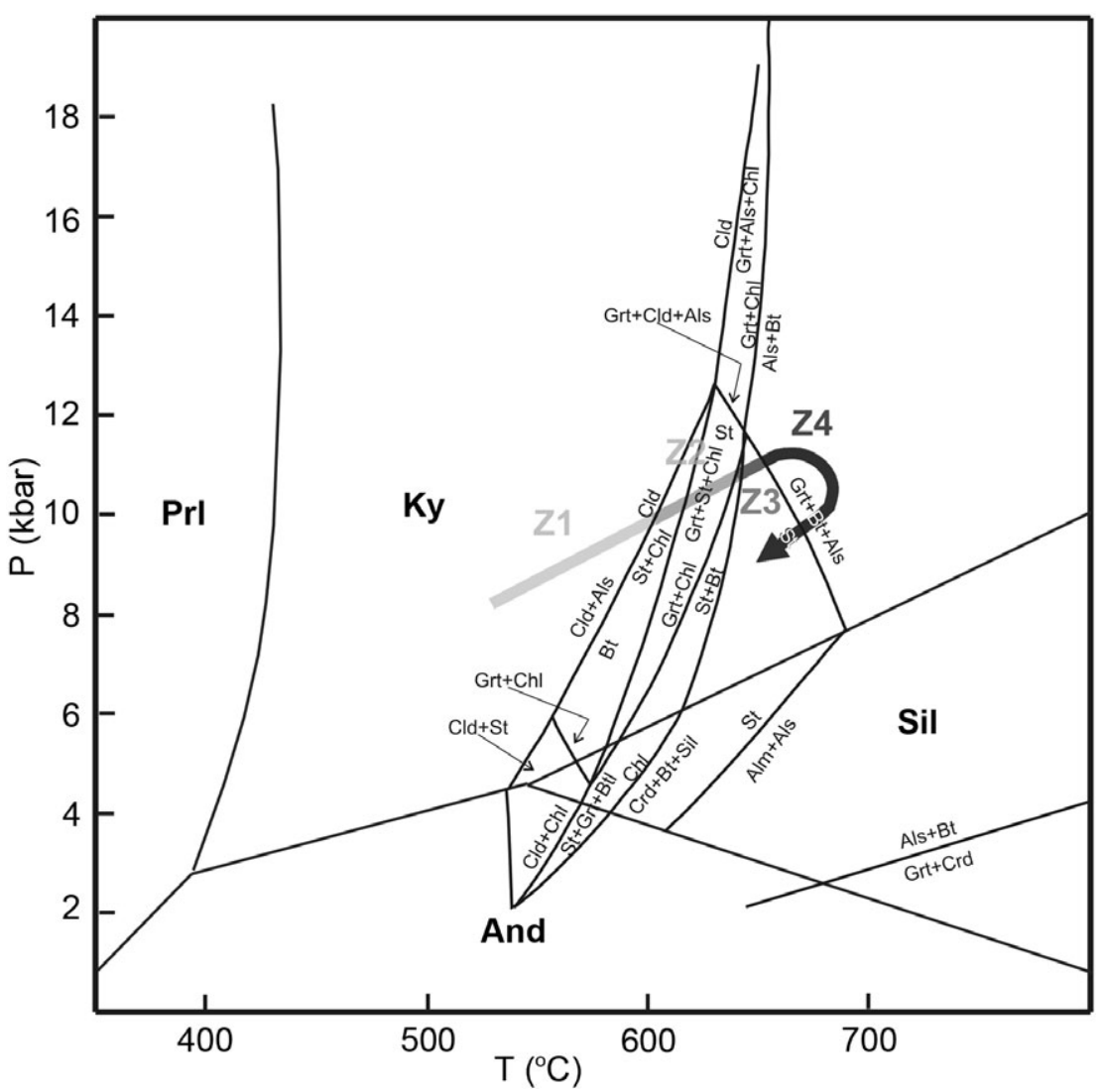

Fig. $6 \mathrm{~K}_{2} \mathrm{O}-\mathrm{FeO}-\mathrm{MgO}-\mathrm{Al}_{2} \mathrm{O}_{3}-\mathrm{SiO}_{2}-\mathrm{H}_{2} \mathrm{O}$ (KFMASH) petrogenetic grid (modified from Spear \& Cheney 1989; Spear \& Cheney unpubl. data) with the pressure-temperature (P-T) path marked for the Isbjørnhamna Group rocks. above a temperature of $630^{\circ} \mathrm{C}$ at $11 \mathrm{kbar}$. The results from geothermobarometry are consistent (sample 124) at ca. $646^{\circ} \mathrm{C}$ and a maximum pressure of ca. 11 kbar. Additionally, the probable homogenization of garnet from this sample suggests that the rock was metamorphosed under relatively high-grade conditions.

Rocks from the north-eastern part of the study area contain both kyanite and staurolite. This mineral assemblage is stable in a relatively small $\mathrm{P}-\mathrm{T}$ field at temperatures of ca. $640-680^{\circ} \mathrm{C}$ and pressures of ca. 9-10 kbar. The geothermobarometrical results for this variety of the Revdalen mica schists yielded a temperature of ca. $628^{\circ} \mathrm{C}$ and pressures of $6.6-8.77 \mathrm{kbar}$. The $628^{\circ} \mathrm{C}$ temperature is fairly consistent with the stability field of the Grt $+\mathrm{Bt}+\mathrm{St}+\mathrm{Ky}$ paragenesis, and the pressure is within error of the expected pressure field.

In the remaining two samples (217 and 125), no Al-saturated phases were observed, as expected for the low bulk $\mathrm{Al}$ content in these rocks. Nevertheless, the temperatures of $636^{\circ} \mathrm{C}$ for sample 217 and $597^{\circ} \mathrm{C}$ for sample 125 are reasonable. Sample 217 was collected not far away from samples 218 and 124, and a similar temperature estimation therefore seems likely. Sample 125 comes from the area at the south-eastern extremity of the
Revdalen Formation, and the temperature obtained is comparable with that calculated for sample 126 (Fig. 5).

As the transformation of kyanite into sillimanite or andalusite is not documented in the studied rocks, cooling possibly took place within the kyanite stability field. Accordingly, the retrograde part of the P-T path obtained for the Revdalen mica schists does not cross the boundaries of sillimanite and andalusite stability fields (Fig. 6).

\section{Cooling rate}

Using previous geochronological data (Manecki et al. 1998; Majka et al. 2008) and thermometrical results presented in this paper, it is possible to reconstruct the cooling history of the Isbjørnhamna Group. Manecki et al. (1998) reported 585-575 $\mathrm{My}{ }^{40} \mathrm{Ar}-{ }^{39} \mathrm{Ar}$ cooling ages for muscovite from the Isbjørnhamna Group and a $616 \mathrm{My}{ }^{40} \mathrm{Ar}-{ }^{39} \mathrm{Ar}$ cooling age for hornblende from the overlying Eimfjellet Group. The closing temperatures for muscovite and hornblende are ca. $350^{\circ} \mathrm{C}$ and ca. $550^{\circ} \mathrm{C}$, respectively. Majka et al. (2008) obtained a $643 \mathrm{My}$ $\mathrm{U}-\mathrm{Th}$-total $\mathrm{Pb}$ age for monazites located both in the matrix of mica schists and enclosed in garnet porphyro- 


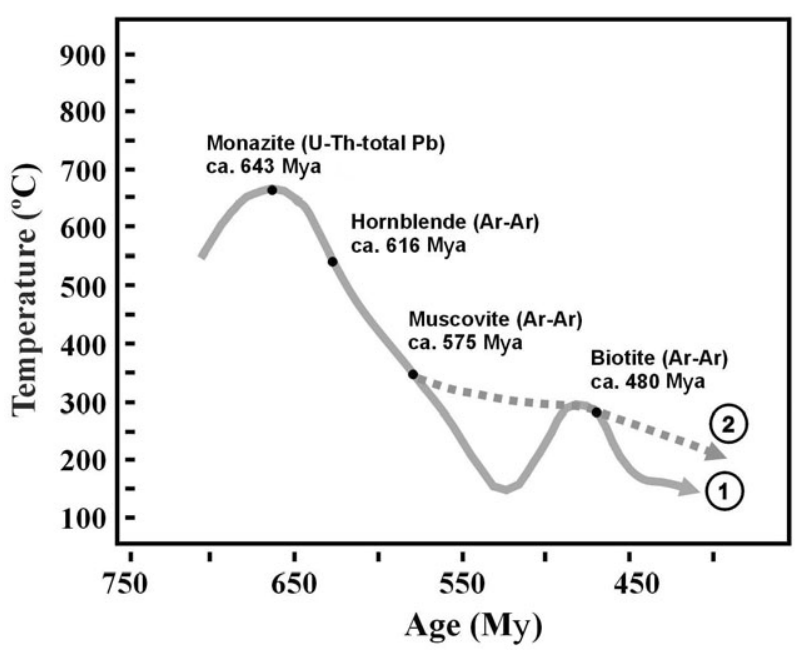

Fig. 7 Hypothetical cooling paths for the Isbjørnhamna Group, based on data published by Manecki et al. (1998), Majka et al. (2008) and this paper. Path 1 assumes moderate reheating at ca. 480 Mya, whereas path 2 postulates a decrease in the cooling rate from 575 Mya onwards.

blasts, constraining the growth of garnet in the Isbjørnhamna Group at 643 Mya. From the data mentioned above and with three points on the agetemperature diagram, we construct a nominal cooling path for the Neoproterozoic metamorphic volcanic terrane (Fig. 7). The generally smooth shape of the cooling path suggests a cooling rate of ca. $5^{\circ} \mathrm{C} \mathrm{My}^{-1}$. Such a cooling rate corresponds well with those reported from the Neoproterozoic Pan-African orogens (e.g., Möller et al. 2000). On average, cooling rates increase through geological time, and are an order of magnitude faster in Phanerozoic than in Precambrian settings (Dunlap 2000). Despite the unavoidable simplifications, the compilation of temperature-time (T-t) paths by Willigers et al. (2002) shows that a cooling rate around $5^{\circ} \mathrm{C} \mathrm{My}^{-1}$ is typical of Neoproterozoic orogens. Two possible forms of the T-t path for the Isbjørnhamna Group are proposed (Fig. 7). One assumes a moderate reheating at ca. 480 Mya, the approximate time of metamorphism in the northern tectonic block of Wedel Jarlberg Land (Mazur et al. 2009). The other postulates a decrease of the cooling rate from 575 Mya onwards. Further thermochronological studies are necessary to differentiate between these two possibilities.

\section{Concluding remarks}

The Revdalen Formation is a $<200 \mathrm{~m}$ thick continuous horizon that provides an excellent marker for investigating lateral changes in P-T metamorphic conditions. On the basis of the metamorphic mineral zonation and $\mathrm{P}-\mathrm{T}$ estimates, an increase of P-T conditions from west (Rålstranda area) to east (Revdalen Valley area) is observed. Only the slight south-eastward temperature decrease in the Fugleberget area departs from this general trend. Taking into account the thermometric results from the Skoddefjellet mica schists, a similar trend in temperature change can be extrapolated for the entire Isbjørnhamna Group. Maximum temperatures were obtained from the core of the Ariebreen anticline, whereas the calculated temperatures continuously decrease toward the limbs of this antiform and the western part of the study area. This relationship indicates that large-scale folding of the Isbjørnhamna Group occurred after the peak of metamorphism. Because the folds are crosscut by the VKZ, displacement along this shear zone must have been even later. Indeed, the isograds defined for the Revdalen Formation are oblique to the trend of the VKZ. In summary, the peak temperature and pressure conditions of Neoproterozoic metamorphism are estimated at ca. $670^{\circ} \mathrm{C}$ and $\leq 1 \mathrm{l} \mathrm{kbar}$. The geothermobarometric results are consistent with previous preliminary estimates of the P-T rockforming conditions (Smulikowski 1965; Czerny et al. 1993; Majka et al. 2004).

The microstructural observations show that the pervasive fabric of the Isbjørnhamna rocks formed under conditions close to the peak of metamorphism. As the constructed isograds are oblique to the foliation and lithological contacts, the penetrative deformation must have slightly preceded the peak temperature. The latter was followed by the folding of already developed foliation before the initiation of the VKZ. Considering that the VKZ was developed in the Early Ordovician (Mazur et al. 2009), the structural grain of the Isbjørnhamna Group and the entire southern tectonic block of Wedel Jarlsberg Land must have been formed in Neoproterozoic to Cambrian times.

The $\mathrm{T}-\mathrm{t}$ path of the Isbjørnhamna Group shows cooling at a rate of ca. $5^{\circ} \mathrm{C} \mathrm{My}^{-1}$, interpreted to be related to slow erosion controlled exhumation, rather than rapid uplift connected to tectonic activity. Notably, cooling continued undisturbed at least until the Early Ordovician, the time of postulated juxtaposition of the Neoproterozoic complex against the northern part of Svalbard's southwestern terrane.

Our data confirm that the southern tectonic block of Wedel Jarlsberg Land represents a fragment of a Neoproterozoic orogen, with a well-preserved structural grain and metamorphic zonation. This Neoproterozoic domain seems to be entirely exotic compared with Svalbard's remaining terranes, and is only weakly overprinted by Caledonian metamorphism. The Neoproterozoic terrane could not have been derived from the North American margin, as postulated for the rest of Svalbard's crustal 
fragments (Gee $\&$ Tebenkov 2004). Instead, its presence is more in line with models suggesting large-scale strike-slip displacements during the Early Palaeozoic assembly of the Svalbard Archipelago (e.g., Harland \& Gayer 1972; Harland 1985; Gee \& Page 1994). The most straightforward explanation for the origin of the Neoproterozoic terrane is a derivation from the Timanide belt of northeastern Europe. However, such a correlation has two important implications that require further verification and discussion. Firstly, the Neoproterozoic orogeny must have commenced at least before the opening of the Iapetus Ocean, as the Svalbard Archipelago is separated from Europe by Caledonian sutures (Gee $\delta$ Tebenkov 2004). Secondly, the linkage between southwestern Svalbard and the Timanide belt cannot be reconciled with the large-scale Early Palaeozoic rotation of Baltica that has been postulated by Hartz \& Torsvik (2002). Ongoing studies characterizing the metamorphic, structural and magmatic histories of Neoproterozoic circum-Arctic terranes are necessary in order to better constrain Neoproterozoic paleogeographic reconstructions and the proposed younger tectonic evolution models for the region (Amato et al. 2009).

\section{Acknowledgements}

This research was supported by MNiSzW grant no. 2P04D03930. JM was also supported by the Swedish Institute, Visby Programme and Ymer-80 Foundation. We are grateful to two anonymous reviewers for their constructive comments improving the manuscript, and to L. Jeżak and P. Dzierżanowski (Warsaw University) for their assistance with the electron microprobe analyses.

\section{References}

Amato J.M., Toro J., Miller E., Gehrels G.E., Farmer L., Gottlieb E. \& Till A.B. 2009. Late Proterozoic-Paleozoic evolution of the Arctic Alaska-Chukotka terrane based on $\mathrm{U}-\mathrm{Pb}$ igneous and detrital zircon ages: implications for Neoproterozoic paleogeographic reconstructions. Geological Society of America Bulletin 121, 1219-1235.

Armstrong H.A., Nakrem H.A. \& Ohta Y. 1986. Ordovician conodonts from the Bulltinden Formation, Motalafjella, central-western Spitsbergen. Polar Research 4, 17-23.

Balashov J.A., Tebenkov A.M., Ohta Y., Larionov A.N., Sirostkin A.N., Gannibal L.F. \& Ryungenen G.I. 1995. Grenvillian U-Pb zircon ages of quartz porphyry and rhyolite clasts in a metacoglomerate at Vimsodden, southern Spitsbergen. Polar Research 14, 291-302.

Bergh S.G., Braathen A. \& Andresen A. 1997. Interaction of basement-involved and thin-skinned tectonism in the Tertiary fold-thrust belt of central Spitsbergen, Svalbard. AAPG Bulletin 81, 637-661.
Birkenmajer K. 1958. Preliminary report on the stratigraphy of the Hecla Hoek Formation in Wedel Jarlsberg Land, Vestspitsbergen. Bulletin de l'Academie Polonaise des Sciences, Serie des Sciences Chimiques, Geologiques et Geographiques 6, 143-150.

Birkenmajer K. 1975. Caledonides of Svalbard and plate tectonics. Bulletin of the Geological Society of Denmark 24, $1-19$.

Birkenmajer K. 1981. The geology of Svalbard, the western part of the Barents Sea, and the continental margin of Scandinavia. In A.E.M. Nairn et al. (eds.): The Arctic Ocean. The ocean basins and margins. Part 5. Pp. 265-329. New York: Plenum.

Birkenmajer K. 1991. The Jarlsbergian unconformity (Proterozoic/Cambrian boundary) and the problem of Varangian tillites in South Spitsbergen. Polish Polar Research 12, 269-278.

Bjørnerud M. 1990. Upper Proterozoic unconformity in northern Wedel-Jarlsberg Land, southwest Spitsbergen: lithostratigrapby and tectonic implications. Polar Research 8 , 127-140.

Braathen A., Bergh S.G. \& Maher H.D. 1995. Structural outline of a Tertiary basement-cored uplift/inversion structure in western Spitsbergen, Svalbard: Kinematics and controlling factors. Tectonics 14, 95-119.

Broska I. \& Majka J. 2008. Transformation of phosphates to silicates: from metasomatism to hydrothermal breakdown? In D. Harlov \& I. Broska (eds.): Mineral equilibria, metasomatism and mass transport: evolution and stabilisation of rock on a fluid-rich world. Proceedings from MIMET 2008 Workshop Smolenice, Slovak Republic, April 8-10. Pp. 18-21. Bratislava: Geological Institute, Slovak Academy of Sciences.

Bucher K. \& Frey M. 1994. Petrogenesis of metamorphic rocks. Berlin: Springer.

Czerny J., Kieres A., Manecki M. \& Rajchel J. 1993. Geological map of the SW part of Wedel Jarlsberg Land, Spitsbergen 1:25 000. Kraków: Institute of Geology and Mineral Deposits.

Czerny J., Majka J., Gee D.G., Manecki A. \& Manecki M. 2010. Torellian Oregony: evidence of a Late Proterozoic tectonometamorphic event in southwestern Svalbard's Caledonian basement. In H.A. Nakrem et al. (eds.): 29th Nordic Geological Winter Meeting. Abstracts and Proceedings of the Geological Society of Norway 1 2010. Pp. 35-36. Trondheim: Geological Society of Norway.

Dallmann W.K., Andresen A., Bergh S.G., Maher H.D. \& Ohta Y. 1993. Tertiary fold-and-thrust belt of Spitsbergen (Svalbard). Norsk Polarinstitutt Meddelelser 128. Oslo: Norwegian Polar Institute.

Dallmann W.K., Hjelle A., Ohta Y., Salvigsen O., Maher H.D., Bjørnerud M., Hauser E.C. \& Craddock C. 1990. Geological map of Svalbard 1:100 000, B11G Van Keulenfjorden. Norsk Polarinstitutt Temakart 15. Oslo: Norwegian Polar Institute.

Dallmeyer R.D., Peucat J.J. \& Ohta Y. 1990. Tectonothermal evolution of contrasting metamorphic complexes in northwestern Spitsbergen (Biskayerhalvøya): evidence 
from 40Ar/39Ar and Rb-Sr mineral ages. Geological Society of America Bulletin 102, 653-663.

Dunlap W.J. 2000. Nature's diffusion experiment: the cooling-rate cooling-age correlation. Geology 28, 139-142.

Ferry J.M. 2000. Patterns of mineral occurrence in metamorphic rocks. American Mineralogist 85, 1573-1588.

Gee D.G. 1986. Svalbard's Caledonian terranes reviewed. Geologiska Föreningens Stockholm Förhandlingar 108, 284-286.

Gee D.G., Johansson Å., Ohta Y., Tebenkov A.M., Krasil'ščhikov A.A., Balashov Y.A., Larionov A.N., Gannibal L.F. \& Ryungenen G.I. 1995. Grenvillian basement and a major unconformity within the Caledonides of Nordaustlandet, Svalbard. Precambrian Research 70, 215-234.

Gee D.G. \& Page L.M. 1994. Caledonian terrane assembly on Svalbard: new evidence from 40Ar/39Ar dating in Ny Friesland. American Journal of Science 294, 1166-1186.

Gee D.G. \& Tebenkov A.M. 2004. Svalbard: a fragment of the Laurentian margin. In D.G. Gee \& V. Pease (eds.): The Neoproterozoic Timanide orogen of eastern Baltica. Geological Society Memoir 30. Pp. 191-206. Bath: Geological Society.

Harland W.B. 1972. Early Palaeozoic faults as margins of Arctic plates in Svalbard. In J. Gill (ed.): International Geological Congress. Twenty-fourth session. Section 3. Tectonics. Pp. 230-237. Montreal: International Geological Congress. Harland W.B. 1985. Caledonide Svalbard. In Gee D.G. \& Sturt B.A. (eds.): The Caledonide orogen-Scandinavia and related areas. Pp. 999-1016. Chichester: Wiley.

Harland W.B. \& Gayer R.A. 1972. The Arctic Caledonides and earlier oceans. Geological Magazine 109, 289-314.

Harland W.B., Hambry M.J. \& Waddams P. 1993. The Vendian geology of Svalbard. Norsk Polarinstitutt Skrifter 193. Oslo: Norwegian Polar Institute.

Harland W.B., Scott R.A., Auckland K.A. \& Snape L. 1992. The Ny Friesland orogen, Spitsbergen. Geological Magazine 129, 679-708.

Hartz E.H. \& Torsvik T.H. 2002. Baltica upside-down: a new plate-tectonic model for Rodinia and the Iapetus Ocean. Geology 30, 255-258.

Hellman F.J., Gee D.G., Johansson Å. \& Witt-Nilsson P. 1997. Single-zircon $\mathrm{Pb}$ evaporation geochronology constrains basement-cover relationships in the Lower Hecla Hoek Complex of northern Ny Friesland, Svalbard. Chemical Geology 137, 117-134.

Henry D.J., Guidotti C.V. \& Thomson J.A. 2005. The Ti-saturation surface for low-to-medium pressure metapelitic biotites: implications for geothermometry and Ti-substitution mechanisms. American Mineralogist 90, 316-328.

Holdaway M.J. 2000. Application of new experimental and garnet Margules data to the garnet-biotite geothermometer. American Mineralogist 85, 881-892.

Holdaway M.J. 2001. Recalibration of the GASP geobarometer in light of recent garnet and plagioclase activity models and versions of the garnet-biotite geothermometer. American Mineralogist 86, 1117-1129.
Holdaway M.J., Mukhopadhyay B., Dyar M.D., Guidotti C.V. \& Durow B.L. 1997. American Mineralogist 82, 582-595.

Holtedahl O. 1926. Notes on the geology of northwestern Spitsbergen. Skrifter om Svalbard og Ishavet 8. Oslo: Norwegian Polar Institute.

Janák M., Plašienka D., Frey M., Cosca M., Schmidt S.T., Lupták B. \& Méres S. 2001. Cretaceous evolution of a metamorphic core complex, the Veporic unit, Western Carpathians (Slovakia): P-T conditions and in situ 40Ar/ 39Ar UV laser probe dating of metapelites. Journal of Metamorphic Geology 19, 197-216.

Janots E. , Brunet F., Goffé B., Poinssot C., Burchard M. \& Cemič L. 2007. Thermochemistry of monazite-(La) and dissakisite-(La): implications for monazite and allanite stability in metapelites. Contributions to Mineralogy and Petrology 154, 1-14.

Johansson Å., Larionov A.N., Gee D.G., Ohta Y., Tebenkov A.M. \& Sandelin S. 2004. Grenvillian and Caledonian tectono-magmatic activity in northeasternmost Svalbard. In D.G. Gee \& V. Pease (eds.): The Neoproterozoic Timanide orogen of eastern Baltica. Geological Society Memoir 30. Pp. 207-232. Bath: Geological Society.

Krasil'ščikov A.A. 1979. Stratigraphy and tectonics of the Precambrian of Svalbard. In T.S. Winsnes (ed.): The geological development of Svalbard during the Precambrian, Lower Palaeozoic, and Devonian. Symposium on Svalbard's geology. Oslo, 2-5 June, 1975. Norsk Polarinstitutt Skrifter 167. Pp. 73-80. Oslo: Norwegian Polar Institute.

Lowell J.D. 1972. Spitsbergen Tertiary orogenic belt and the Spitsbergen fracture zone. Geological Society of America Bulletin 83, 3091-3102.

Majka J. 2003. Warunki metamorfizmu skat grupy Isbjørnhamna (Ziemia Wedel Jarlsberga, Spitsbergen) w świetle badań geotermobarometrycznych. (Metamorphic conditions of the Isbjørnhamna Group rocks [Wedel Jarlsberg Land, Svalbard] in the light of geothermobarometry.) Master's thesis, AGH-University of Sciences and Technology, Kraków.

Majka J. \& Budzyń B. 2006. Monazite breakdown in metapelites from Wedel Jarlsberg Land, Svalbardpreliminary report. Mineralogia Polonica 37, 61-69.

Majka J., Czerny J. \& Manecki M. 2004. Petrographical characteristics of the Isbjørnhamna Group Rocks (Wedel Jarlsberg Land, Spitsbergen). Mineralogical Society of Poland, Special Papers 24, 279-282.

Majka J., Gee D.G., Larionov A., Czerny J., Wypych A. \& Manecki M. 2007. Neoproterozoic zircon age from anathectic pegmatite, Isbjørnhamna Group (Wedel Jarlsberg Land, Svalbard). ICAM V. 5th International Conference on Arctic Margins. 3-5 September 2007. Tromsø, Norway. NGF Abstracts and Proceedings 2, 2.

Majka J., Mazur S., Manecki M. Czerny J. \& Holm D. 2008. Late Neoproterozoic amphibolite facies metamorphism of a pre-Caledonian basement block in southwest Wedel Jarlsberg Land, Spitsbergen: new evidence from U-Th-Pb dating of monazite. Geological Magazine 145, 822-830.

Manecki M., Holm D.K., Czerny J. \& Lux D. 1998. Thermochronological evidence for late Proterozoic 
(Vendian) cooling in southwest Wedel Jarlsberg Land, Spitsbergen. Geological Magazine 135, 63-69.

Mazur S., Czerny J., Majka J., Manecki M., Holm D.K., Smyrak A. \& Wypych A. 2009. A strike-slip terrane boundary in Wedel Jarlsberg Land, Svalbard, and its bearing on correlations of SW Spitsbergen with the Pearya terrane and Timanide belt. Journal of the Geological Society 166, 529-544.

Möller A., Mezger K. \& Schenk V. 2000. U-Pb dating of metamorphic minerals: Pan-African metamorphism and prolonged slow cooling of high-pressure granulites in Tanzania, East Africa. Precambrian Research 104, 123-147.

Ohta Y. 1979. Blue schists from Motalafjella, western Spitsbergen. In T.S. Winsnes (ed.): The geological development of Svalbard during the Precambrian, Lower Palaeozoic, and Devonian. Symposium on Svalbard's geology. Oslo, 2-5 June 1975. Norsk Polarinstitutt Skrifter 167. Pp. 171-217. Oslo: Norwegian Polar Institute.

Ohta Y. 1982. Lithostratigraphy of the Hecla Hoek rocks in central Nordaustlandet and their relationships to the Caledonian granitic-migmatitic rocks. In Y. Ohta (ed.): Hecla Hoek rocks in central and western Nordaustlandet. Norsk Polarinstitutt Skrifter 178. Pp. 41-60. Oslo: Norwegian Polar Institute.

Pettersson C.H., Tebenkov A.M., Larionov A.N., Andresen A. $\delta$ Pease V. 2009. Timing of migmatization and granite genesis in the northwestern terrane of Svalbard, Norway: implications for regional correlations in the Arctic Caledonides. Journal of the Geological Society 166, 147-158.

Peucat J.J., Ohta Y., Gee D.G. \& Bernard-Griffiths J. 1989. $\mathrm{U}-\mathrm{Pb}, \mathrm{Sr}$, and $\mathrm{Nd}$ evidence for Grenvillian and latest
Proterozoic tectonothermal activity in the Spitsbergen Caledonides, Arctic Ocean. Lithos 22, 275-285.

Sandford K.S. 1956. The stratigraphy and structure of the Hecla Hoek Formation and its relationship to a subjacent metamorphic complex in North-East Land (Spitsbergen). Quarterly Journal of the Geological Society London 112, 339-362.

Scrutton C.T., Horseield W.T. \& Harland W.B. 1976. Silurian fossils from western Spitsbergen. Geological Magazine 113, 519-523.

Smulikowski W. 1965. Petrology and some structural data of lowermetamorphic formations of the Hecla Hoek Succession in Hornsund, Vestspitsbergen. Studia Geologica Polonica 18. Warsaw: Institute of Geological Sciences, Polish Academy of Sciences.

Spear F.S. 1993. Metamorphic phase equilibria and pressure-temperature-time paths. Washington D.C.: Mineralogical Society of America.

Spear F.S. \& Cheney J.T. 1989. A petrogenetic grid for pelitic schists in the system $\mathrm{SiO}_{2}-\mathrm{Al}_{2} \mathrm{O}_{3}-\mathrm{FeO}-\mathrm{MgO}-\mathrm{K}_{2} \mathrm{O}-\mathrm{H}_{2} \mathrm{O}$. Contributions to Mineralogy and Petrology 101, 149-164.

Thompson A.B. 1976. Mineral reactions in pelitic rocks. II. Calculation of some $\mathrm{P}-\mathrm{T}-\mathrm{X}(\mathrm{Fe}-\mathrm{Mg})$ phase relations. American Journal of Science 276, 425-454.

Tracy R.J. 1982. Compositional zoning and inclusions in metamorphic minerals. Reviews in Mineralogy 10, 355-394.

Willigers B.J.A., van Gool J.A.M., Wijbrans J.R., Krogstad E.J. \& Mezger K. 2002. Post-tectonic cooling of the Nagssugtoqidian orogen and a comparison of contrasting cooling histories in Precambrian and Phanerozoic orogens. The Journal of Geology 110, 503-517. 